\begin{tabular}{|c|c|c|}
\hline 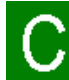 & $E$ & $\begin{array}{l}\text { CENTRE FOR } \\
\text { EUROPEAN }\end{array}$ \\
\hline & & $\begin{array}{l}\text { POLICY } \\
\text { STUDIES }\end{array}$ \\
\hline
\end{tabular}

CEPS POLICY BRIEF NO. 38

OCTOBER 2003

\title{
REFORM OF CORPORATE GOVERNANCE IN THE EU
}

KAREL LANNOO

AND

ARMAN KHACHATURYAN

\begin{abstract}
This Policy Brief criticises the European Commission's proposal to mandate compliance with a local corporate governance code and to set minimum criteria for these codes. It argues that the European Commission missed an opportunity to set a European corporate governance code in the mid-1990s, and that most of the latest spate of proposals are simply reactions to recent events and new legislation in the US. Rather than embarking on a complex exercise in harmonisation, Europe should have built on the strength of its diversity and emphasised that the basic principles of corporate governance are better implemented in the EU than they are in the US.
\end{abstract}

CEPS Policy Briefs are published to provide concise policy-oriented analysis of contemporary issues in EU affairs. Unless otherwise indicated, the views expressed are attributable only to the authors in a personal capacity and not to any institution with which they are associated.

Available for free downloading from the CEPS website (http://www.ceps.be)

(c) Copyright 2003, Karel Lannoo and Arman Khachaturyan 


\section{CONTENTS}

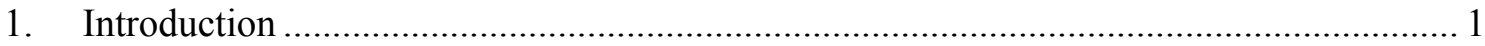

2. The Choice of Finance and Its Regulatory Implications ............................................... 2

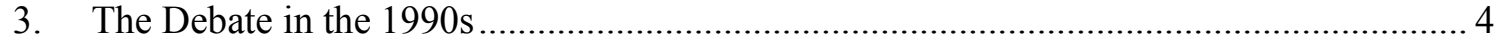

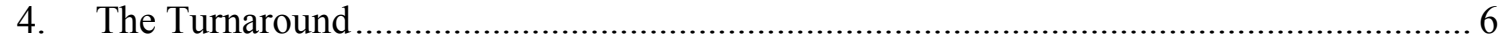

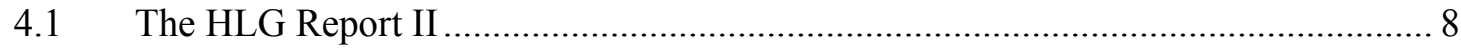

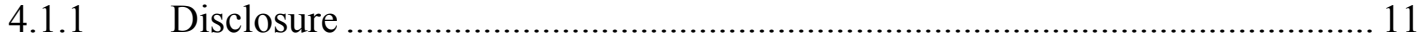

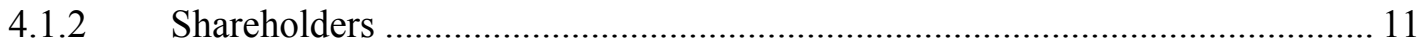

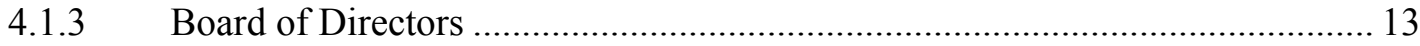

4.2 The Commission's Communications on Corporate Governance and the Statutory Audit ................................................................................... 14

4.2.1 Commission Communication on corporate governance .................................. 14

4.2.2 The Commission Communication on reinforcing

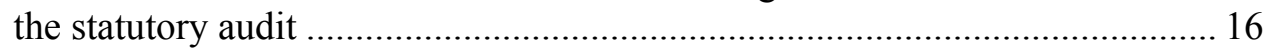

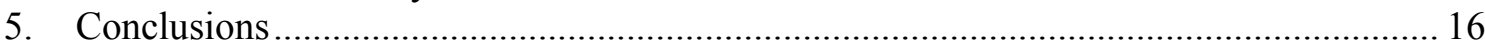

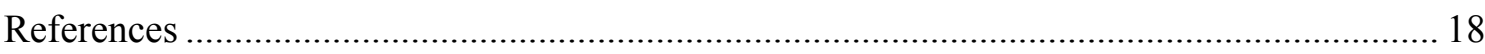

List of Tables

1. The layers of securities market regulation ..................................................................... 4

2. CEO remuneration in Europe in multiples of manufacturing

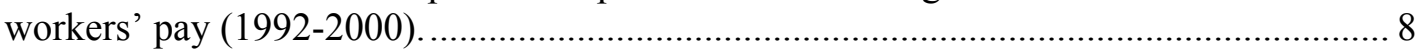

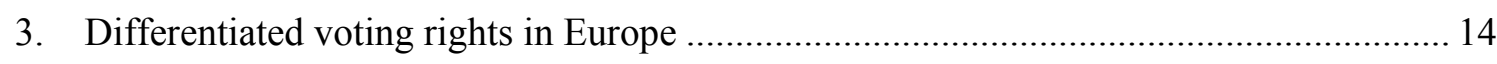

\section{List of Figures}

1. Average pay of top US 100 CEOs in multiples of worker pay ….................................. 8

2. Composition of average pay of top US 100 CEOs............................................

3. The ownership structure in the EU vs. the US

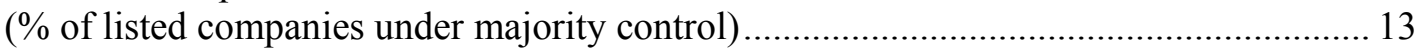

4. The ownership structure in the EU vs. the US

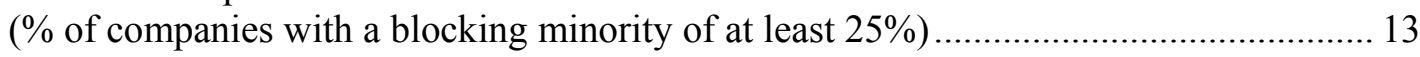




\title{
REFORM OF CORPORATE GOVERNANCE IN THE EU
}

\author{
CEPS POLICY BRIEF NO. 38/OCTOBER 2003 \\ KAREL LANNOO \\ AND \\ ARMAN KHACHATURYAN ${ }^{*}$
}

\section{Introduction}

On 21 May 2003, the European Commission presented its long-awaited Communication on enhancing corporate governance and a second Communication on reinforcing statutory audit in the EU (European Commission, 2003a and 2003b). These Communications follow in the wake of the EC-sponsored studies on corporate governance in Europe, the recent problems with "America Inc.", the adoption of the Sarbanes-Oxley Act in the United States in July 2002 publication of the High Level Group Report II. Together, they recommend a long series of legislative proposals and reforms (20 in total), and almost as many proposals for recommendations and further studies in these areas.

The Communications' far-reaching proposals came somewhat as a surprise. The corporate governance debate has been going on for over 10 years in Europe and flourished at national level. The Commission repeatedly emphasised that there was no need to intervene at the EU level as the codes that were set at national level were fairly similar in their scope and recommendations. It was argued that corporate governance was an excellent area in which to apply the "soft law" approach and that harmonisation in this area would jeopardise the strength of the diversity of the national systems. Moreover, the arguments advanced in support of EU intervention were not convincing.

High-profile corporate scandals in the US have changed this perception fundamentally. In a very short period of time, harmonisation of corporate governance standards came to be seen as "essential" for Europe in order to rebuild the confidence of investors and to foster business competitiveness and efficiency (European Commission, 2003a, p. 3). Further harmonisation of audit standards and oversight of the profession is also all of a sudden a high priority.

Such a dramatic change cannot disguise the fact that the Commission's new stance is above all reactive. It missed an opportunity to set a European code in the mid-1990s that could have explicitly acknowledged the greater respect accorded the fundamentals of corporate governance in the EU as compared to the US. Moreover, the Commission is probably now over-reacting and initiating legislation without any real need to do so.

This paper analyses the European corporate governance debate and examines both the report entitled A Modern Regulatory Framework for Company Law in Europe prepared by the High Level Group of Company Law Experts (2002a) (hereinafter referred as HLG Report II) and the European Commission's Communications on the subject. It is structured as follows. Section 2 frames the debate on corporate governance in the context of the broader discussion

\footnotetext{
* Karel Lannoo is CEPS Chief Executive and head of the financial markets research programme, and Arman Khachaturyan is a Visiting Fellow at CEPS. Comments by Gert-Jan Vossestein are gratefully acknowledged. The paper has also benefited from helpful suggestions and comments at the Symposium on the Reform of Corporate Governance in Europe and the US at Tilburg University (June 2003).
} 
in corporate finance circles on market vs. bank finance and the subsequent regulatory response. The paper builds upon the fact that the European system is largely bank-dominated, which is characterised by a structure of concentrated ownership and differentiated voting rights. Although such a system might be inefficient from a corporate finance perspective, its regulation is less cumbersome and less costly. Section 3 briefly addresses the corporate governance discussions in the EU member states. In particular, it points out that a variety of initiatives and studies in the area of corporate governance have all reached the same conclusion that there is no need for an EU corporate governance code, advocating instead a soft-law and best-practices approach. Section 4 discusses the recommendations put forward in the HLG Report II in the area of corporate governance. It argues that the High Level Group and subsequently the Commission failed to demonstrate that the proposed measures will rebuild investor confidence or foster business competitiveness and efficiency. Moreover, the proposed recommendations are in line with measures aimed at mitigating agency problems with dispersed non-controlling shareholders and managers. These measures are in fundamental disequilibrium with control and ownership structures in the EU and would therefore at best a negligible impact on EU companies and possibly at the worst, a damaging effect. A final section puts forward conclusions.

\section{The Choice of Finance and Its Regulatory Implications}

Unlike the US, Europe is by and large a bank-based system. Despite the fact that the liberalisation of European financial markets in the single market programme and the start of monetary union were intended to stimulate direct market financing, the effects have been limited so far. Total assets of the banking sector in the EU, measured as a percentage of GDP, have risen from $161 \%$ in 1990 to $239 \%$ in 2001 . In contrast, total assets of US commercial banks stood at $78 \%$ of GDP in 2001 , increasing slowly from $59 \%$ in $1990 .{ }^{1}$ Moreover, the total value of US bonds and equity outstanding in the markets, measured as a percentage of GDP, is roughly twice as large as in the EU.

From a corporate finance perspective, such a situation is not very efficient. The banking market may be dominated by a few players, who may not be interested in financing certain higher-risk segments of the market. They may also charge too high a price for underwriting certain risks. A market-based system or an environment that offers the choice of both systems mitigates this problem.

From a regulatory perspective, however, establishing the regulation for a bank-based system is simpler and less costly compared to a market-based system. It suffices to set a crude minimum capital ratio and to have some risk-weighting of the different asset classes, as set in the Basel Capital Accord. It also requires a small group of supervisors to enact this agreement.

The regulation and supervision of a market-based system, on the other hand, are much more complex, multi-layered and costly requiring years, if not decades to put in place and run smoothly (see Table 1). The regulation of securities markets requires the active participation of market intermediaries such as accounting firms, investment banks, law firms, ratings agencies and stock exchanges. They put their reputation at stake when supporting a certain security. These intermediaries reap the benefit, or bear the cost, of supporting any security. The second tier of intermediaries consists of investment and pension funds, which provide market demand for securities, and the financial press. The corporate scandals in the US have amply demonstrated the importance of these "reputational intermediaries", but also the fragility of such a structure.

\footnotetext{
${ }^{1}$ See OECD (2003).
} 
Table 1. The layers of securities market regulation

\begin{tabular}{|l|l|}
\hline Issuers & Equity and debt securities \\
\hline Reputational intermediaries & $\begin{array}{l}1^{\text {st }} \text { tier: Accounting firms, investment banks, ratings agents, law } \\
\text { firms and stock exchanges } \\
2^{\text {nd }} \text { tier: Investment funds, pension funds, financial press }\end{array}$ \\
\hline Self-regulatory organisations & $\begin{array}{l}\text { Professional federations, standard-setters (accounting and } \\
\text { audit), takeover panels, stock exchanges, central securities } \\
\text { depositories (CSDs) }\end{array}$ \\
\hline Government institutions & Securities commissions, accounting oversight boards, courts \\
\hline Laws & Securities law, company law, bankruptcy law, criminal law \\
\hline
\end{tabular}

Source: Adapted from Lannoo (2001).

The regulation of a market-based system requires active participation of self-regulatory organisations (SROs). They control the intermediaries and can be subdivided into voluntary (professional organisations) and mandatory (SROs mandated and controlled by the government) organisations. By law, intermediaries are liable for faulty information or fraudulent practices.

The regulation of a market-based system requires a well-developed legal mechanism for efficient dispute resolution to back up its operations. In general, market-based systems are characterised by small dispersed shareholdings, very few of which has an incentive or the resources to monitor executive performance. Managers are given a high magnitude of discretionary power in which they can pursue corporate strategy and objectives (although within the scope of the business judgment rule and general presumptions of fairness). Shareholder passivity and discretionary managerial power result in traditional "principalagent" types of conflict. Shareholders can either exit or litigate for any alleged managerial misconduct such as a lack of adequate disclosure, insider dealing, interested transactions and fraud. In the absence of an efficient dispute resolution system that can mandate coercive measures and sanctions for non-compliance, any litigation can lead to long and tedious court cases. This system also requires an army of well-trained lawyers and an efficient judiciary.

Adequate corporate governance is part of a well-functioning market-based system, but it is also an element of its complexity. Corporate governance is an amalgam of internal company rules, soft law approaches (codes) and statutory legislation. Despite many years of discussion and general consensus on the basic principles of good corporate governance, it seems that market economies are still far from having the framework for adequate enforcement in place, and that violation of the basic principles is very common. This leads to further legislation of previously non-legislated areas of corporate governance. The US Sarbanes-Oxley Act and the EC's Corporate Governance Communication are good examples of this trend.

It has sometimes been argued that the US is well aware that a market-based system is more expensive to establish, but that this is precisely the reason why the US is trying to export it. The US Securities and Exchange Commission (SEC) has actively helped emerging markets to put in place the basic structures for the regulation and supervision of securities markets. In several of these cases, however, emerging markets realised that it was easier to follow the bank-based model first before establishing a market-based model. Since resources were limited, and the transition to a well-functioning market economy had to be robust, it was easier to start with a bank-intermediated financing model. This was the case in most of the Central and East European countries, for example. Some of these countries, such as the Czech 
Republic, Hungary and Poland, did however try to follow the other route, but only for a limited period of time, and/or without success. ${ }^{2}$

\section{The Debate in the 1990s}

During the last decade, the corporate governance debate has spread to almost all European countries, resulting in the adoption of codes that are broadly parallel in their scope and recommendations. In general, they address the role of the board of directors, financial reporting, the role of the auditors and the function of the Annual General Meeting.

Having the most developed stock market in the EU, the UK pioneered the corporate governance debate in the EU. The debate resulted in the Cadbury Code, adopted in 1992 as the listing rule for the London Stock Exchange. The debate successively spread to the Netherlands, France and most other European countries, all of which adopted one or more codes. Germany was one of the last countries to follow this trend and only adopted a corporate governance code in 2002.

As stated above, the corporate governance codes adopted at the national level throughout the EU are fairly similar in nature. Given this situation, the European Commission consulted on several occasions with experts as to whether EU action was required in this area. In 1995, a study conducted by Ernst \& Young for the Commission concluded that the EU should set framework principles for corporate governance of large companies in a directive, which could be transposed into the individual national legal systems either by law or within the framework of a national "best practice" code. Some harmonisation of voting rights would also be desirable to increase the proportionality between the subscribed capital and the voting rights held (European Commission, 1995). In February 1997, the Commission started a consultation on the simplification of company law. At a conference debating the results held in December 1997, the Commission proposed the creation of a Company Law Forum, in order to better prepare Community initiatives.

Further to the adoption of the Financial Services Action Plan in May 1999 (FSAP, 1998) ${ }^{3}$, the Commission launched a study on corporate governance codes in the EU member states, and the need for any action at EU level (Weil, Gothshal \& Menges, 2002). This study found a high degree of convergence between the national corporate governance codes, and therefore did not advocate the adopt of a single code at the EU level. Since the various codes emanating from the member states appeared to support a convergence of governance practices, we argue that the Commission should not expend energy on the development of a code applicable to all companies in the EU, but should allow market forces to progress in this direction over time.

What has been missing in the local debates, however, is the European dimension. Although European market integration constitutes one of the sources of pressure on national corporate governance systems to adapt, the debate on reforming and improving the corporate control

\footnotetext{
${ }^{2}$ The empirical evidence suggests that mere transposition of laws cannot bring the same efficiency results in another institutional setting. Gilson (1996) argues that any reform measure makes sense only in the framework of a country-specific institutional environment. Pistor, Raiser \& Gelfer (2000) evaluate the role of the law, legal enforcement, compliance norms and institutions ("legality") in the process of building capital markets in transition economies in 1990-98. They report that formal legal protection variables do not have a statistically significant relationship with market capitalisation, unlike legality. The authors conclude that external finance will not flow into investments in transition economies, even if they radically improve the shareholder and creditor protection rules.

${ }^{3}$ The FSAP outlined a list of measures to be agreed upon by 2005 in an effort by the European Commission to create a fully integrated capital market
} 
system was essentially focused on the domestic markets. The national corporate governance committees were mostly, if not uniquely, composed of national representatives, and the European dimension of the issue was hardly invoked.

Seen from an international perspective, corporate governance codes are more broadly developed and better implemented in Europe than they are in the US. Splitting the role of chairman and chief executive, for example, is standard practice in numerous national codes in Europe, and is well implemented, whereas the opposite is the rule in the US.

Furthermore executive remuneration has never spiralled to the levels it has in the US, and stock options are much less developed. Its rise in the EU is attributed to fixed salaries and cash bonuses rather than share-option plans. The median CEO remuneration and particularly share and share-related remuneration have been constantly increasing in the US since 1990.

Table 2 shows the dynamics of CEO pay in multiples of manufacturing working pay in the EU. In the period 1992-2000, CEOs in the UK are reported to have earned the highest increase in remuneration in the EU in multiples of manufacturing workers' pay. In 2000, they earned 25 times more than a manufacturing worker did.

In contrast to the EU, the ratio of CEO pay to manufacturing worker pay in the US is dramatic in its magnitude. It peaked to 1,046 in 1999 and then dropped to 531 and 411 in 2000 and 2001, respectively (see Figure 1).

Moreover, share and share-related remuneration in the US has been constantly rising (see Figure 2). Over 1980-2001, the percentage of the fixed component of the pay package of the top 100 CEOs in the US dropped from $43 \%$ to $17 \%$, whereas the share and share-related component has risen from $56 \%$ to $8 \%$.

Table 2. CEO remuneration in Europe in multiples of manufacturing workers' pay (1992-2000)

\begin{tabular}{lcccccccc}
\hline & 1992 & 1996 & 1997 & 1998 & 1999 & 2000 & $\begin{array}{c}2000 \\
\text { (ths) }\end{array}$ & $\begin{array}{c}\text { Increase } \\
\text { (times) }\end{array}$ \\
\hline $\mathrm{NL}$ & 10 & 9 & 14 & 13 & 17 & 22 & 621 & 2.20 \\
$\mathrm{SW}$ & 8 & 7 & 11 & 11 & 13 & 13 & 440 & 1.63 \\
$\mathrm{BE}$ & 12 & 12 & 13 & 14 & 18 & 19 & 655 & 1.58 \\
$\mathrm{UK}$ & 16 & 17 & 18 & 23 & 24 & 25 & 720 & 1.56 \\
$\mathrm{IT}$ & 14 & 16 & 16 & 17 & 20 & 22 & 568 & 1.57 \\
$\mathrm{DE}$ & 10 & 8 & 11 & 10 & 13 & 11 & 422 & 1.10 \\
$\mathrm{ES}$ & 17 & 16 & 14 & 15 & 17 & 17 & 399 & 1.00 \\
$\mathrm{FR}$ & 17 & 15 & 15 & 15 & 15 & 15 & 540 & 0.88 \\
\hline
\end{tabular}

Source: Soderstrom et al. (2003). 
Figure 1

Average pay of top US 100 CEOs in multiples of worker pay

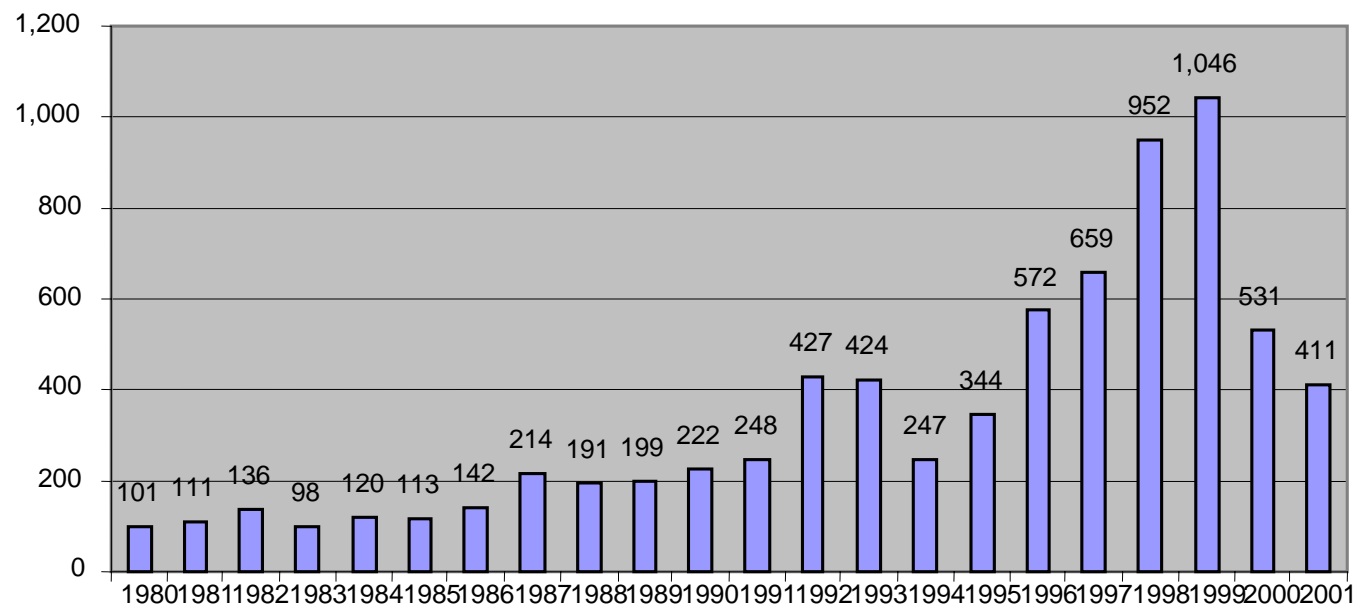

Sources: Piketty \& Saez (2001), Hall (2002) and various issues of Business Week.

Figure 2

Composition of average pay of top US 100 CEOs

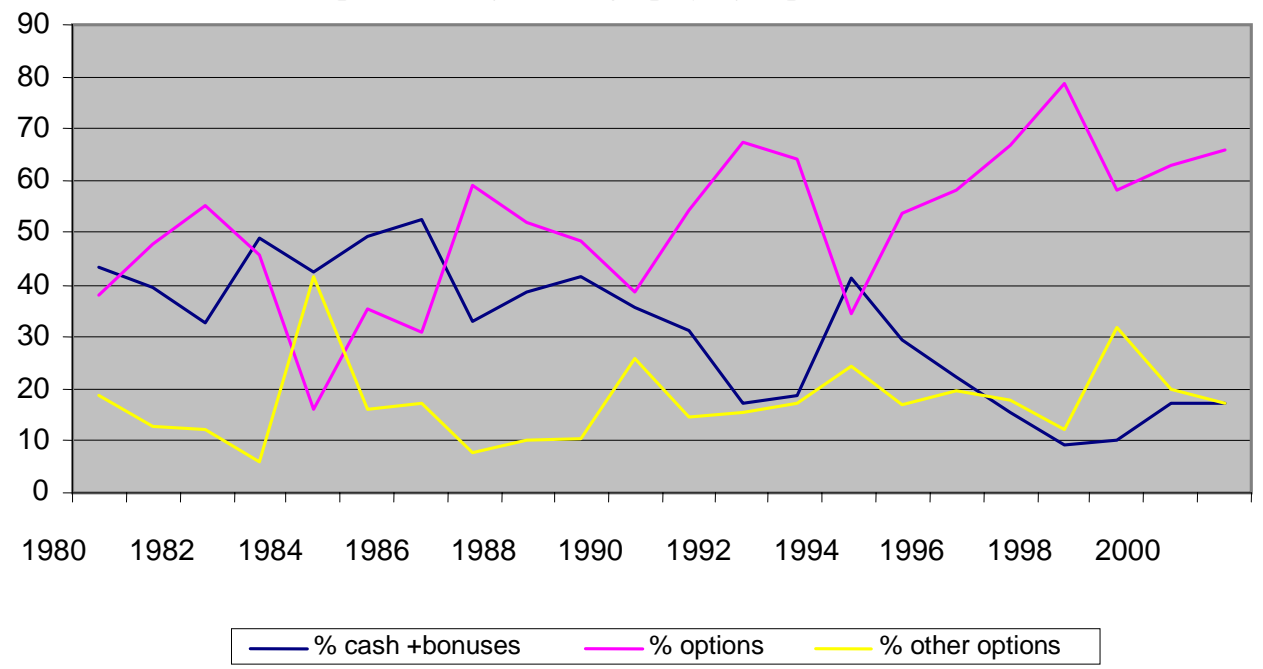

Sources: Piketty \& Saez (2001), Hall (2002) and various issues of Business Week.

\section{The Turnaround}

Until very recently, the EU explicitly refrained from taking any initiative in the area of corporate governance. This field was seen to be the prerogative of member states. Differences in standards were not seen to distort the free movement of goods or services, and the 
subsidiarity clause came into play. This stance changed markedly, however, as a result of the Enron affair and the adoption of the Sarbanes-Oxley Act in the US.

Any Community-wide measure in the EU should be evaluated against the standards of subsidiarity and proportionality. The test of subsidiarity requires that the Commission should bear the burden of proving that member states are not able to implement the measure as efficiently as it could be implemented at EU level, whereas the test of proportionality requires that any Community-wide action taken should be proportional to the objective pursued.

In discussing EU action in the area of corporate governance, a distinction should be made between company and securities law measures. In the area of securities market regulation, the EU has been fairly successful. Several measures have already been adopted and more are awaiting adoption, based on the principles of mutual recognition and the single passport. Nevertheless, the level of harmonisation and enforcement of the initial measures left much to be desired. This was addressed in the FSAP (cited above) and the Lamfalussy Report (2001), which provided the necessary underpinnings for the new regulatory framework called for in the FSAP and also gave it much-needed publicity. Moreover, Commission also launched an ambitious harmonisation project including the adoption of the International Accounting Standards (IAS) to provide a uniform basis for financial reporting and information disclosure in the EU for listed companies and issuers.

In the area of company law, progress has been limited. The most important reform measures have failed after decades of efforts at harmonisation. Overall, the more they tried to harmonise "corporate governance" the less successful they were. One major proposal intended to harmonise company structures in the, now abandoned, 5th Company Law Directive. Another proposal aimed at easing cross-border mergers of companies (10th company law directive). The most publicised harmonisation effort has been the establishment of uniform rules for takeovers across the EU. This proposal attempted to create a "level playing field" through proportionality between risk-bearing capital and control, and introduced the break-through rule. Once again, the efforts to harmonise corporate governance structures and control systems have been blocked by the member states, each pursuing its own interests. The only real progress was the agreement on the regulation for a European company statute (Societas Europea, SE) in October 2001, which can in fact be considered a $16^{\text {th }}$ company law regime in the EU (see Box 1).

The rejection by the European Parliament of the draft take-over bids directive in June 1999, and the collapse of Enron in November 2001 accelerated EU policy action. The Commission instituted the High Level Group of Company Law Experts (HLG) to advise it on the reform of the takeover bids regulation in the EU. The Oviedo Informal Ecofin Council (April 2002) extended the mandate of the HLG to advise it on the reform of corporate governance in view of the Enron disaster.

\section{Box 1. The European Company Statute}

The European Company Statute (ECS), on which a final agreement was reached in October 2001, will give companies operating in more than one member state the option of being established as a single European company (Societas Europaea or SE) under Community law. This will enable them to operate throughout the EU under one set of rules and with a unified management and reporting system, rather than being subject to all the different national laws of each member state in which they have subsidiaries. The EU regulation will allow an SE to be created in any one of the following four forms: 
- as a holding company promoted by public or private limited companies from at least two different member states;

- as a joint subsidiary of companies from at least two different member states;

- through the merger of two or more existing public or private limited companies located in at least two member states; or

- by transformation of a national company that has operated in two (or more) member states for at least two years, without the need to dissolve the company.

The SE must have its registered office in the same member state as the head office. It can be moved from one member state to another on the basis of a simple procedure. The SE offers the possibility of one-tier and two-tier boards, in view of the fact that both are common in the EU. The minimum capital of an SE is $€ 120,000$, in order to ensure that small- and mediumsized enterprises have the opportunity to make use of it. Many items are left to national law, however, the most important one being taxation.

An SE can only be created if there is consensus on the degree of worker involvement, which is defined in a separate directive. If it proved impossible to negotiate a mutually satisfactory arrangement, then a set of standard principles, laid down in the annexe to the directive, will apply. However, the SE could also be used as a structure to circumvent heavy worker representation rules in some member states, as long as these do not represent more than $50 \%$ in the holding company SE model or $25 \%$ following the merger SE model.

The SE should not be dismissed as another bureaucratic invention. On the contrary, it may lead European business to consider re-incorporating as a European company and could allow them to simplify their organisational structure. It will, for example, allow large corporations to rethink their organisational structure, and to re-organise themselves along specific lines of activity, rather than having to incorporate on a country-by-country basis. Legal structures could in this sense coincide with the most effective business configuration.

From a regulatory competition point of view, it could be considered as a $16^{\text {th }}$ company law model in which the EU which may exert pressure on other company law models to adapt over time. It may thus, from this perspective, be seen as a more useful way to bring about convergence in company law systems in the EU rather than going for outright harmonisation.

Source: Lannoo \& Levin (2002).

\subsection{The HLG Report II}

The HLG Report II, which was issued on 4 November 2002, recommends measures for the improvement of internal mechanisms of corporate governance regimes in the EU. It covers issues such as shareholders' rights and minority protection, duties of the board, the role of non-executive directors, managerial remuneration and managerial responsibility for financial statements, audit practices and EU coordination mechanisms.

The report's recommendations are based on the concept of "shareholder democracy", which stems from its previous report on takeover harmonisation across the EU. ${ }^{4}$ Though presumably

\footnotetext{
4 Grossman \& Hart (1988) and Harris \& Raviv (1988) provide a rigorous analytical framework of (non)optimality conditions of the one-share/one-vote rule in the context of takeovers. Although the proposed settings differ in some respects, both studies conclude that the distribution of voting rights affects the value of the firm and under qualifying conditions (almost always), the one-share/one-vote rule is not in any event Pareto
} 
both the HLG and the European Commission associate shareholder democracy with the oneshare/one-vote regime, neither of them has ever clearly stated this connection nor endorsed the unconditional one-share/one-vote regime for listed companies in the EU. ${ }^{5}$

The proposed recommendations are in line with efficiency measures of the US-type dispersed ownership structures, but they are not effective in mitigating the agency problems associated with concentrated shareholder structures in the EU. Figures 3 and 4 demonstrate ownership concentration in the US and some selected EU member states. ${ }^{6}$ The percentage of listed companies under majority control on the NYSE is $1.7 \%$ as compared to $68 \%$ in Austria. The percentage of companies with a blocking minority of at least $25 \%$ is $93.6 \%$ in Belgium as compared to $5.2 \%$ in the US.

Figure 3. The ownership structure in the EU vs. the US (percentage of listed companies under majority control)

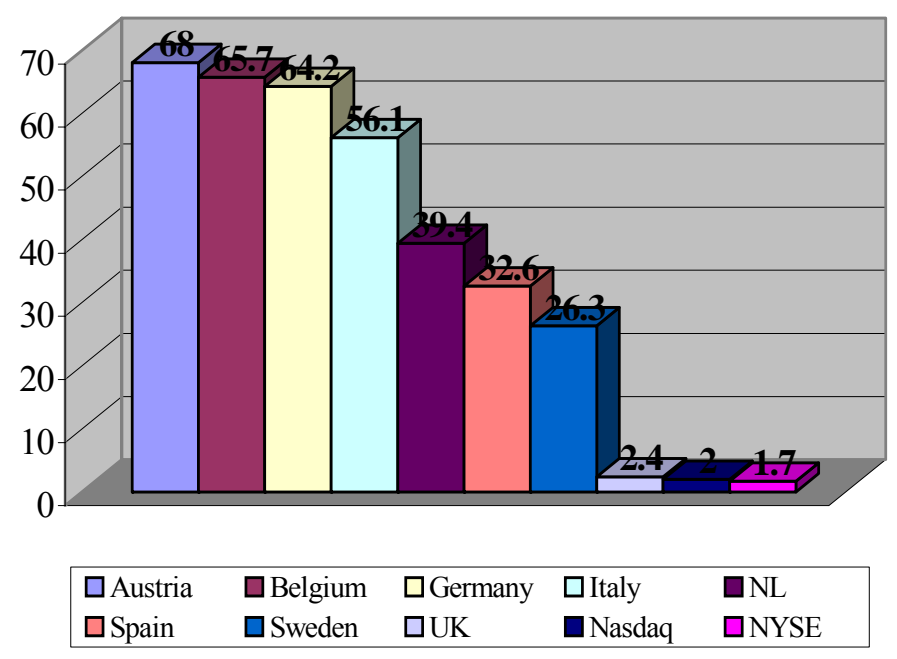

optimal. There will be wealth-increasing deviations from the one-share/one-vote rule. While this concept might be politically marketable, its economic foundations are indeed very questionable.

In the context of takeovers, the HLG promulgates that shareholders are the owners of the company and they should take the ultimate decision to sell the company. The HLG Report on Takeovers I (2002b) endorses the principle of proportionality (not one-to-one match) between the risk-bearing capital (a concept previously unknown to economics although the economic logic associates it with cash flow rights) and decision-making. Through endorsing the breakthrough rule, the HLG effectively redefines the concept of ownership, shifting it to those with cash-flow rights and giving them the power to decide. Thus, paradoxically, by promoting shareholder democracy and decision-making, the HLG indeed at best demotes and at worst oppresses real ownership rights, and hence shareholder democracy. See the proposed $13^{\text {th }}$ directive on takeovers.

${ }^{5}$ See also the Communication on corporate governance where the EC argues that it intends to conduct a study on the effects of the principle of proportionality between capital and control. What the EC simply argues for is a general test of proportionality rather than the one-share/one-vote match in deciding on the benefits of shareholder democracy.

${ }^{6}$ See Barca \& Becht (2001). 
Figure 4. The ownership structure in the EU vs. the US (percentage of companies with a blocking minority of at least 25\%)

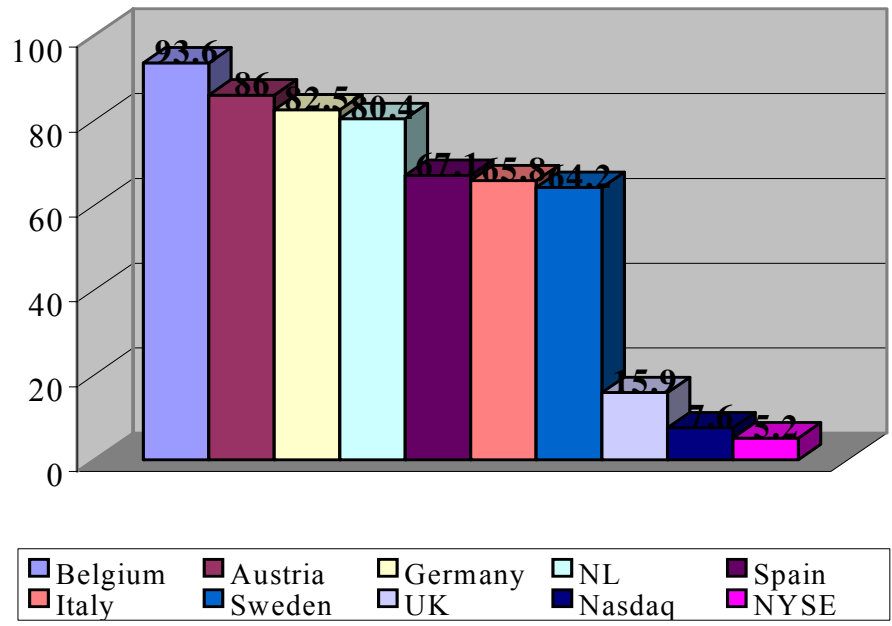

Table 3 demonstrates differentiated voting rights in the EU. Sweden leads the list with $55 \%$ of its companies employing differentiated voting rights to separate voting rights from cash flow rights. Such a system allows controlling the company without affecting the liquidity thereof.

Table 3. Differentiated voting rights in Europe

\begin{tabular}{lcc}
\hline Country & $\begin{array}{c}\text { Number of } \\
\text { companies }\end{array}$ & $\begin{array}{c}\text { Proportion of companies with } \\
\text { differentiated voting rights (\%) }\end{array}$ \\
\hline Sweden & 334 & 0.55 \\
Italy & 208 & 0.41 \\
Finland & 129 & 0.36 \\
Denmark & 210 & 0.33 \\
UK & 1953 & 0.24 \\
Ireland & 69 & 0.23 \\
Austria & 99 & 0.23 \\
Germany & 704 & 0.18 \\
France & 607 & 0.03 \\
Spain & 632 & 0.00 \\
Portugal & 87 & 0.00 \\
Belgium & 130 & 0.00 \\
\hline
\end{tabular}

Source: Bennedsen \& Nielsen (2002).

In general, EU corporate structures are characterised by different kinds and magnitudes of agency problems. They should be tackled by different policy measures rather than mandating a US-type regulatory response which is both a misleading and an ineffective way to enhance 
the efficiency of the corporate governance system in the EU. Nevertheless, the HLG Report II endorses the unconditional merits and supremacy of the US corporate governance model for the EU. ${ }^{7}$

\subsubsection{Disclosure}

The HLG argues that a proper disclosure regime has a crucial importance in company law structures in general and in corporate governance in particular. It recommends disclosing key elements of corporate governance and its practices in an annual corporate governance statement regardless of whether its provisions are mandatory or voluntary. In so far as this makes the corporate decision-making process and practices more transparent, this is a step forward.

It is interesting to observe that the HLG Report II recognises that disclosure is a moving target and that the priority of items to be disclosed changes over time. In the context of the annual corporate governance statement, the HLG implicitly supports the benefits of regulatory competition by stating that the member states should be in charge of setting "a system of flexible and efficiently adaptable subordinate rules," while the European Commission should only have a coordinating role.

\subsubsection{Shareholders}

The HLG Report's recommendation with respect to shareholders can be classified into two broad categories: rights of the shareholders and the responsibilities of institutional investors.

\section{Shareholders' rights}

The HLG Report II observes that the power of influence over the company should be conferred upon its shareholders. It further argues that particularly in the case of listed companies, shareholders should act both on their own behalf and on behalf of other stakeholders in monitoring corporate performance. The HLG Report II argues that shareholders should act as "watchdogs", and refers to shareholders as exercising influence. However, while there might be common objectives, shareholders' needs and objectives are quite different from those of other stakeholders. Any such monitoring on behalf of other stakeholders will be undertaken if and only if its benefits to the shareholders exceed the costs of monitoring, no matter how much benefit other stakeholders incur.

The HLG Report II endorses what is called a "rational apathy" when shareholders prefer to sell out shares rather than monitor and influence corporate performance. Nevertheless, it is not clear why this might prove disadvantageous as the HLG Report II points out. The right to exit is a conscious exercise of freedom of choice. Shareholders generally rationalise their decisions on the basis of the costs and benefits of being shareholders and by the costs and benefits of monitoring. Although it is true that small dispersed shareholders may be reluctant to incur the costs of monitoring as its benefits will be shared by all shareholders (the traditional free-rider problem), controlling shareholders have both the incentive and the resources to do so.

\footnotetext{
${ }^{7}$ The universal efficiency of this system, however, has come under criticism. Roe (1998) for example argues that "it is natural to associate American institutions, such as a vibrant stock market and diffuse ownership of large firms, as both inevitable and efficient." Nevertheless Seligman (1986), Gilson (1987) and Jarrel \& Poulsen (1988) challenge the widespread perception of the superiority of "American institutions" with respect to the enactment of state anti-takeover regimes and controversies on the one-share/one-vote regime.
} 
The HLG Report II also makes specific recommendations with respect to shareholders' rights to ask questions, to table resolutions, to vote in absentia and to participate in general meetings by means of electronic communication. Special investigative rights should be conferred upon minority shareholders holding a minimum of $5-10 \%$ of the share capital to require special investigation by a court or an appropriate administrative agency. The HLG argues that an EC directive might be required to facilitate cross-border voting. This is a welcome move insofar as it would enhance shareholder participation at the EU level.

The HLG Report II argues for equivalent (but not equal) opportunities and facilities in shareholders' participation, information and communication rights across the EU to allow enhanced decision-making.

\section{Responsibilities of institutional investors}

The HLG Report II observes that institutional investors have a key role in the corporate governance of companies in which they invest. They have fiduciary responsibilities vis-à-vis their beneficiaries, which creates a situation necessitating regulation. The HLG argues that there are double-edged agency problems with institutional investors insofar as they enter into fiduciary relationships with their beneficiaries and also have investment relationships with the companies they invest in. Nevertheless, the HLG Report makes recommendations only with respect to the relationship between institutional investors and their beneficiaries. ${ }^{8}$ On grounds of possible agency problems between institutional investors and their beneficiaries (such as internal reward schemes that may be paid to the detriment of beneficiaries), the HLG Report requires institutional investors to disclose to their beneficiaries their investment policies, along with when and how they have been exercised.

Nevertheless, the role of institutional investors should not have been formalised either in the HLG Report or in the Commission Communications. Imposing such a requirement does not address the agency problems between institutional investors and their beneficiaries. It is just because investors want to minimise the time and resources devoted to monitoring that they entrust their shares to institutional investors. The latter carry out efficient monitoring and control (punishment) of executive management by exercising their voting rights or by threatening to exercise them. Instead of mandating costly and burdensome disclosure procedures for institutional investors, the European Commission should think of ways to strengthen their fiduciary responsibilities and the enforcement system in an effort to deal with agency problems between institutional investors and their beneficiaries at their source and to mitigate their magnitude.

Another mechanism that can correct the misalignment of interests between institutional investors and their clients is contractual regulation. The rights and responsibilities of institutional investors and their beneficiaries can be regulated by contracts at least as efficiently as by imposing a mandatory regime. In particular, the internal reward schemes of many institutional investors are tied to the performance of the portfolios they hold, which acts both as a motivating and a disciplining mechanism.

\footnotetext{
${ }^{8}$ The Commission argues in the Communication on corporate governance that it will take the necessary steps in the medium term to amend the existing EU regulations on institutional investors to foster the role of institutional investors in the companies in which they have investments.
} 


\subsubsection{Board of Directors}

\section{The structure and functions of the board}

The HLG Report II argues that a strong and balanced board is a key for good corporate governance. The board should closely monitor managerial strategies and performance in an effort to bridge the gap between uninformed shareholders and fully informed managers. Nevertheless, shareholders are not necessarily uninformed unless they do not bother to be informed, nor are managers ever fully informed.

The HLG Report recognises that one-tier and two-tier board systems reflect legal and institutional legacies, and that neither of them precludes good corporate governance regimes. The HLG finds it inadvisable to mandate a particular board system for the EU and offers companies a choice between the two systems. This move indeed facilitates a wider "issuer choice" regime in the EU.

The HLG Report confirms that controlling shareholder structures mitigate the problems of executive monitoring in the EU. At the same time, however, they create another set of agency problems between minority shareholders and controlling shareholders on the one hand and the minority owners and managers on the other. Consequently, controlling shareholder structures necessitate monitoring by non-executive directors in the areas of executive nomination, executive remuneration and auditing. Non-executive directors should therefore be independent in the majority.

According to the HLG Report, executive nomination should be entrusted to the nomination committee. The remuneration committee should make sure that executive remuneration policy and individual remuneration are approved by shareholders, properly accounted for, and disclosed in annual accounts. The audit committee should be responsible for monitoring the internal accounting policies and practices as well as the risk management system. It should also conduct external audit selection, control audit performance and ensure auditor independence.

In line with the Sarbanes-Oxley Act, the HLG proposes collective executive responsibility based on the standard of the wrongful trading rule which might involve sanctions and executive disqualification across the EU.

\section{The structure of the board and its efficiency implications}

Paradoxically, the HLG both recognises the problems of controlling structures and mandates a typical solution for non-controlling dispersed structures. The nature and magnitude of agency problems of controlling shareholder structures in the EU differ significantly from that of dispersed shareholder structures in the US. If indeed there is a lesson to be learned from the US experience, it is that these agency problems can be addressed through the US type of judicial doctrine and judicial review rather than imposing a costly yet inappropriate nonexecutive structure for the listed companies in the EU - not to mention the further need for standards of independence and competence.

It would have been a more viable and efficient step forward if the Commission had introduced measures that could effectively constrain the private benefits of control by controlling shareholders. By promoting their own interest through general oversight, majority shareholders also promote that of the minority. Nevertheless, controlling shareholders can 
unilaterally and disproportionally benefit from their holdings in three ways: through operating, selling control and freeze-outs. ${ }^{9}$

There are two aspects of operations: i) business and strategic decisions and ii) direct dealing with the corporation. As for business and strategic decisions, the standard of enforcement in the US is the business judgment rule. ${ }^{10}$ In the US the intrinsic fairness standard ${ }^{11}$ applies to any transaction between the controlling shareholder and the corporation. If the standards of the business judgment rule and intrinsic fairness rule are met, then there is no need to regulate such activity.

As for the second source of private benefits associated with the sale of control, the US again subjects it to general judicial review if a dispute arises. In general, if i) the controlling shareholder acquires minority shares in anticipation of sale with proper disclosure and ii) the acquirer purchases a controlling shareholding not to extract disproportionate benefits of control, there is no need to regulate the flow of the value from one controlling shareholder to another.

For freeze-out transactions, the rules are more complex. The basic legal rule governing these transactions, however, is the rule of fairness which is further bifurcated into the rules of fair dealing and fair price.

Hence, this would suggest that judicial doctrines can effectively restrict the amount of control benefits accrued by controlling shareholders. It is also clear that any such doctrine and judicial review does not eliminate the private benefits of control. They just provide benchmarks for standards. Therefore, the introduction of Delaware-type judicial doctrines for controlling transactions and subjecting them to a simple judicial review, rather than trying to regulate them extensively, can be seen as a step forward.

\subsection{The Commission's Communications on Corporate Governance and the Statutory Audit}

\subsubsection{The Commission's Communication on corporate governance}

The Communication on corporate governance fully and unconditionally endorses the HLG Report. It announces 17 legislative and 7 non-legislative measures in the area of corporate governance. The Communication proposes the harmonisation of the collective responsibility of board members at the European level, the annual disclosure of key elements in corporate governance structures and practices by all EU-listed companies, and the creation of a European Corporate Governance Forum to coordinate the corporate governance efforts of the member states.

The harmonisation of the liability of board members is clearly given in the introduction of the personal liability of the $\mathrm{CFO}$ and $\mathrm{CEO}$ for the financial statements of the company, as introduced by the Sarbanes-Oxley Act. Nevertheless, the SEC maintains that collective

\footnotetext{
${ }^{9}$ See Gilson \& Gordon (2003).

${ }^{10}$ The business judgment rule is a rule granting directors immunity from liability if their actions have been executed in good faith, using sound business judgment and exercised with reasonable care. Section 4.01(a) of the American Law Institute's Principles of Corporate Governance reads: "A director or officer has a duty to the corporation to perform the director's or officer's functions in good faith, in a manner that he or she reasonably believes to be in the best interests of the corporation, and with the care that an ordinarily prudent person would reasonably be expected to exercise in a like position and under similar circumstances..."

${ }^{11}$ The intrinsic fairness standard obliges the controlling shareholder to prove that any transaction between her and the corporation is intrinsically fair.
} 
responsibility, as proposed by the EC, is not equivalent to personal liability; hence the problem for EU companies listed in the US remains.

The centrepiece of the Communication is the requirement that all EU-listed companies must produce an annual statement on corporate governance. Listed companies will be required to include in their annual reports and accounts a coherent statement covering the key elements of their corporate governance structures and practices. At a minimum, this statement should include the following information:

a) the operation of the shareholder meeting and its key powers, the description of shareholder rights and how they can be exercised;

b) the composition and operation of the board and its committees;

c) the shareholders holding major holdings, their voting and control rights as well as key agreements;

d) the other direct and indirect relationships between these major shareholders and the company, and any material transactions with other related parties; and

e) the existence and nature of a risk-management system.

Reference should be made to a local corporate governance code, with which the company complies or in relation to which it explains deviations.

The Commission reiterates that there is no need for a European corporate governance code either on grounds of subsidiarity or proportionality. But it adds at the same time that "a selfregulatory market approach, based solely on non-binding recommendations, is clearly not always sufficient to guarantee the adoption of sound corporate governance practices. (...) Therefore, a common approach should be adopted at EU level with respect to a few essential rules and adequate coordination of corporate governance codes should be ensured."

The end result is a super code for European corporate governance! The Commission firstly harmonises the key elements of the national codes, and secondly mandates compliance with these codes through a legal instrument: a directive. In a very subtle way, the Commission thereby proposes a more far-reaching harmonisation than it has adhered to in the past and even than is currently in place in the member states. It disregards the self-regulatory approach that was followed in all member states and proposes to override the diversity found in national legal systems via an extensive series of harmonising legislation. This legislation encompasses, among others items:

a) the structure of corporations;

b) corporate governance disclosure requirements;

c) an integrated legal framework to facilitate efficient shareholder communication and decision-making;

d) increased disclosure of group structure relations; and

e) enhanced disclosure of institutional investors and their investment and voting policies.

To coordinate these efforts, the Commission proposes to create a European Corporate Governance Forum. Member states should designate a code with which listed companies should comply - since some member states have more than one - and ensure compliance and disclosure. The Forum should aim at coordinating these efforts and will be chaired by the Commission.

The proposals of the Commission also contain some specific problems. The requirement, for example, that listed companies comply with a local code, raises the question of the location of the business. Is it the location of the principal place of business, or is it the location where the 
securities are admitted? In this sense, the Commission's proposal perpetuates the different national codes. It would in this sense be better to explicitly recognise the freedom to choose between codes.

\subsubsection{The Commission's Communication on reinforcing the statutory audit}

The measures as proposed in the statutory audit Communication are probably more useful and more consistent with previous positions of the Commission on the subject, although here also the impact of events across the Atlantic can clearly be noticed. Approximately 2 million statutory audits are conducted annually in the EU subject to member state regulations. Measures proposed by the statutory audit Communication are intended to harmonise both the regulatory framework for statutory audits as well as to enhance their independence and quality. Eventually, these proposals are targeted at defining how audits should be conducted, by which means, and how audit independence and quality should be safeguarded. In an effort to enhance the accuracy and reliability of audited accounts and strengthen public oversight of auditors at member state and EU level, the Commission proposes to modernise the 8th Company Law Directive with a principles-based Directive.

The Communication proposes to create an EU Audit Regulatory Committee (AAC) to decide on implementing measures for the new directive, to be chaired by the Commission. The Communication leaves in the middle whether this Committee should also have a coordinating role of national oversight systems, which would be required to respond to the creation of the Public Company Accounting Oversight Board (PCAOB) under the Sarbanes-Oxley Act in the US, and to show that equivalent measures are in place in the EU. However, the Commission stresses that an EU coordination mechanism is needed. Such a body could "assess the need for registration and oversight requirements of non-EU audit firms that perform audit work for companies whose securities are traded on EU regulated markets". ${ }^{12}$

We would argue that the harmonisation of national systems of oversight should be considered urgently. The actual organisation of public oversight (or the lack thereof) does not inspire much confidence in the auditing profession, and a European coordination mechanism is required to ensure enforcement of rules and to respond to the creation of the PCAOB. Establishment of the European oversight body over the audit profession, however, cannot be foreseen in the short term given the time, procedures and efforts involved in the EU decisionmaking process. Therefore, the prospects of any reasonable compromise in the near future between the US and the EU remain dim.

\section{Conclusions}

Unlike securities market regulation, it is much harder to make a compelling argument for the harmonisation of company law in the EU. Moreover, since the adoption of the European Company Statute in October 2001, a "16th" company law model now exists that will facilitate cross-border operations for companies and stimulate national systems to adapt.

Many of these initiatives stem from the overall view that a bank-based financing system is not efficient and that Europe needs to adapt its regulations to stimulate market financing. Considering the more than decade-long debate on corporate governance and the gross distortions in the US system, however, one may wonder whether market financing is so efficient after all. A proper cost/benefit analysis may be the most useful way to answer this question.

\footnotetext{
${ }^{12}$ European Commission (2003b), p. 8.
} 
The Commission's proposal to set minimum corporate governance requirements for the member states and to mandate compliance with national corporate governance codes represents a far-reaching harmonisation of company law, which is difficult to justify. It will give rise to a lengthy political process, whose outcome is difficult to predict at this stage. Many of the proposals are simply reacting to events and new legislation in the US, rather than taking a pro-active stance.

We would argue that the European Commission missed an opportunity in the mid-1990s to promote a European code, which was taken up by other institutions, i.e. the OECD. It failed to promote the strength of the diversity of Europe's corporate governance systems in response to the failures in US corporate governance. And it is now trying to introduce a far-reaching degree of harmonisation, largely in response to problems that originated in the US and to the legislative measures that were subsequently taken in the US.

In 1995, a CEPS working party argued that the European Commission should promote the adoption by European industry of a self-regulatory code of good practice in corporate governance. This code would set minimum standards for the direction and control of corporations in the EU. It was intended to stimulate the European dimension of corporate governance in the member states, and in the process, it might have pointed to lacunae in national codes and served as a benchmark for the Central and Eastern European countries in the approximation of their laws. In this sense, it would have contributed to convergence in the European corporate governance systems.

Having disregarded the corporate governance issue in the past, the Commission has also failed to respond to events in the US in a pro-active way. It could have emphasised that the basic principles of corporate governance are much better respected in the EU than they are in the US. In this sense, the strength of the diversity could have been highlighted. We argue that given national diversities, the Commission should promote regulatory competition in corporate governance standards. Regulatory competition among national regulators and exchanges is better positioned not only to respond to the real needs of companies and investors but it is also endowed with a more powerful self-correcting mechanism with which to recover from any misguided or inefficient measures. It can also serve as a disciplining mechanism for regulators and exchanges by tying their very existence to their responsiveness to the needs of the real market.

By taking a reactive approach to the Sarbanes-Oxley legislation, however, the Commission seems to be signalling its preference to strengthen its own powers, as the US SEC has done, rather than to build on the strength of the diversity found in the member states. The Commission is essentially trying to accommodate to the changes in US law.

The Commission's proposals also fail to reflect the institutional realities of corporate governance and ownership in the EU. Mandating the US type of corporate regulation is at best unwarranted and at worst a misleading effort to increase the efficiency of the EU-wide corporate governance system. Highly concentrated ownership and control systems create agency problems between controlling and non-controlling shareholders that can be addressed more efficiency through the US type of judicial doctrines and extensive judicial review.

Despite the fact that the Commission's proposals on audit are more useful than those it has put forward on corporate governance, even they are still incomplete. It will require considerable time until the EU can put a sound system of audit oversight in place. This will further delay a possible US-EU regulatory compromise on the oversight of the audit profession. 


\section{REFERENCES}

Barca, F. and M. Becht (2001), The control of corporate Europe, Oxford: Oxford University Press.

Bennedsen, M. and K. Nielsen (2002), The Impact of the Break-Through Rule on European Firms, CEBR Discussion Paper No. 2002-10, Centre for Economic and Business Research, Langelinie, Denmark.

Berkowitz, D., K. Pistor and J-F Richard (1999), Economic Development, Legality and the Transplant Effect, Working Paper, Center for International Development, Harvard University, Cambridge, MA.

European Commission (1995), The Simplification of the Operating Regulations for Public Limited Companies in the EU, Document, December.

European Commission (2002), A Modern Regulatory Framework for Company Law in Europe, Consultative Document of the High Level Group of Company Experts, November.

European Commission (2003a), Modernising Company Law and Enhancing Corporate Governance in the EU - A Plan to Move Forward, Communication from the Commission to the Council and the European Parliament, 21 May.

European Commission (2003b), Reinforcing the Statutory Audit in the EU, Communication from the Commission to the Council and the European Parliament, 21 May.

Financial Services Action Plan (FSAP) (1998) http://europa.eu.int/comm/internal_market/en/finances/general/actionen.pdf

Gilson, R. (1987), "Evaluating Dual Class Common Stock: The Relevance and Substitutes", Virginia Law Review, 73:807.

Gilson, R. (1996), “Corporate Governance and Economic Efficiency: When Do Institutions Matter?”, Washington University Law Quarterly, 74:327.

Gilson, R. and J. Gordon (2003), Controlling Controlling Shareholders, Columbia University Law School WP No. 228, Columbia Law School, NY, NY.

Grossman, S. and O. Hart (1988), "The Costs and Benefits of Ownership: A Theory of Vertical Integration", Journal of Political Economy, 94:691.

Hall, B. (2002), Six Challenges of Equity-Based Pay Design, NBER Working Paper No. 9887 (http://papers.nber.org/papers/W9887).

Harris, M. and A. Raviv (1988), "Corporate Control Contests and Capital Structure", Journal of Financial Economics, 20:55.

High Level Group of Company Law Experts (2002a), A Modern Regulatory Framework for Company Law in Europe (retrievable from

http://europa.eu.int/comm/internal market/en/company/company/modern/consult/report en.pdf).

High Level Group of Company Law Experts (2002b), On Issues Related to Takeover Bids (retrievable from

http://europa.eu.int/comm/internal market/en/company/company/news/hlg01-2002.pdf).

Jarrell, G. and A. Poulsen (1988), "Dual Class Recapitalizations of Antitakeover Mechanisms: The Recent Evidence", Journal of Financial Economics, 20:129.

Lamfalussy, A. (2001), Final Report of the Committee of Wise Men on the Regulation of European Securities Markets, 15 February

http://europa.eu.int/comm/internal_market/en/finances/banks/report.pdf

Lannoo, K. (1995), Corporate Governance in Europe, CEPS Working Party Report No. 12, Centre for European Policy Studies, Brussels. 
Lannoo, K. (1999), “A European Perspective on Corporate Governance”, Journal of Common Market Studies, 37:269.

Lannoo, K. (2001), EU Securities Market Regulation: Adapting to the Needs of a Single Capital Market, CEPS Working Party Report No. 34, Centre for European Policy Studies, Brussels.

Lannoo, K. and M. Levin (2002), An EU Company without an EU Tax?, CEPS Research Report, Centre for European Policy Studies, Brussels.

OECD (2003), Bank Profitability Statistics, Organisation for Economic Cooperation and Development, Paris.

Piketty, T. and W. Saez (2001), Income Inequality in the United States, 1913-1998, NBER Working Paper No. 8467 (www.nber.org/papers/W8467).

Pistor, K., M. Raiser and S. Gelfer (2000), Law and Finance in Transition Economies, Working Paper, Center for International Development, Harvard University, Cambridge, MA.

Roe, M. (1998), "Comparative Corporate Governance", New Palgrave Dictionary of Economics and the Law, 1:339.

Seligman, J. (1986), "Equal Protection in the Shareholder Voting Rights: The One Common Share, One Vote Controversy", George Washington Law Review, 54:687.

Soderstrom, H., E. Berglof, B. Holmstrom, P. Hogfeldt and E. Milgrom (2003), Corporate Governance and Structural Change: European Challenges, SNS Economic Policy Group Report, Center for Business and Policy Studies, Stockholm.

Weil, Gothshal and Menges (2002), Comparative Study of Corporate Governance Codes Relevant to the European Union and Its Member States, on behalf of the European Commission, Internal Market Directorate General. 
$\mathrm{F}$ ounded in 1983, the Centre for European Policy Studies is an independent policy research institute dedicated to producing sound policy research leading to constructive solutions to the challenges facing Europe today. Funding is obtained from membership fees, contributions from official institutions (European Commission, other international and multilateral institutions, and national bodies), foundation grants, project research, conferences fees and publication sales.

\section{GOALS}

- To achieve high standards of academic excellence and maintain unqualified independence.

- To provide a forum for discussion among all stakeholders in the European policy process.

- To build collaborative networks of researchers, policy-makers and business across the whole of Europe.

- To disseminate our findings and views through a regular flow of publications and public events.

\section{ASSETS AND ACHIEVEMENTS}

- Complete independence to set its own priorities and freedom from any outside influence.

- Authoritative research by an international staff with a demonstrated capability to analyse policy questions and anticipate trends well before they become topics of general public discussion.

- Formation of seven different research networks, comprising some 140 research institutes from throughout Europe and beyond, to complement and consolidate our research expertise and to greatly extend our reach in a wide range of areas from agricultural and security policy to climate change, JHA and economic analysis.

- An extensive network of external collaborators, including some 35 senior associates with extensive working experience in EU affairs.

\section{Programme STRUCTURE}

CEPS is a place where creative and authoritative specialists reflect and comment on the problems and opportunities facing Europe today. This is evidenced by the depth and originality of its publications and the talent and prescience of its expanding research staff. The CEPS research programme is organised under two major headings:

\section{Economic Policy}

Macroeconomic Policy

European Network of Economic Policy

Research Institutes (ENEPRI)

Financial Markets, Company Law \& Taxation

European Credit Research Institute (ECRI)

Trade Developments \& Policy

Energy, Environment \& Climate Change

Agricultural Policy

\section{Politics, Institutions and Security}

The Future of Europe

Justice and Home Affairs

The Wider Europe

South East Europe

Caucasus \& Black Sea

EU-Russian/Ukraine Relations

Mediterranean \& Middle East

CEPS-IISS European Security Forum

In addition to these two sets of research programmes, the Centre organises a variety of activities within the CEPS Policy Forum. These include CEPS task forces, lunchtime membership meetings, network meetings abroad, board-level briefings for CEPS corporate members, conferences, training seminars, major annual events (e.g. the CEPS International Advisory Council) and internet and media relations.

Place du Congrès 1 - B-1000 Brussels • Tel: (32.2) 229.39.11 - Fax: (32.2) 219.41.51 • http://www.ceps.be 